\title{
The acid tolerance response of Salmonella typhimurium provides protection against organic acids
}

\author{
Hyung Suk Baik, $†$ Shawn Bearson, Sherry Dunbar $\ddagger$ and John W. Foster
}

Department of

Microbiology and

Immunology, University of South Alabama, College of Medicine, Mobile, AL 36688, USA
Author for correspondence: John W. Foster. Tel: +1 334460 6323. Fax: +1 3344607931. e-mail: fosterj@sungcg.usouthal.edu

\begin{abstract}
Salmonella typhimurium encounters a variety of acid stress situations during pathogenesis and in the natural environment. These include the extreme low pH encountered in the stomach and a less acidic intestinal environment containing large amounts of organic weak acids (volatile fatty acids). The acid tolerance response (ATR) is a complex defence system that can minimize the lethal effects of extreme low pH (pH 3). The data presented illustrate that the ATR can also defend against weak acids such as butyric, acetic or propionic acids. Although an acid shock of pH 4.4 induced the ATR, growth in subinhibitory concentrations of weak acids did not. Various mutations shown to affect tolerance to extreme acid conditions (pH 3) were tested for their effects on tolerance to weak acids. An rpoS mutant lacking the alternative sigma factor $\sigma^{5}$ failed to protect cells against weak acids as well as extreme acid pH. The fur (ferric uptake regulator) and atp (Mgit-dependent ATPase) mutants defective in extreme acid tolerance showed no defects in their tolerance to weak acids. Curiously, the atbR mutant that exhibits increased tolerance to extreme acid pH proved sensitive to weak acids. Several insertions that rendered cells sensitive to organic acids were isolated, all of which proved to be linked to the rpos locus.
\end{abstract}

Keywords: Salmonella typhimurium, acid tolerance, $\sigma^{\mathrm{s}}$, RpoS, volatile fatty acids

\section{INTRODUCTION}

Organic acids such as acetic, propionic and butyric acids are major constituents of some of the more common microbial niches. For example, the intestinal contents of humans can contain levels of volatile fatty acids (VFAs) up to $150 \mathrm{mM}$, produced as a result of fermentation by natural flora (Cummings, 1981; MacFarlane et al., 1992; Cummings et al., 1987). However, organic acids can have deleterious effects on the growth and viability of bacteria and for that reason are commonly used as food preservatives (Salmond et al., 1984; Fay \& Farias, 1975; Eklund, 1980; Bergeim, 1940; Freese et al., 1973). The lethal effects of these weak acids are not only concentration-dependent

†Present address: Department of Microbiology, College of Natural Sciences, Pusan National University, Pusan 609-735, Korea.

¥Present address: Veterans Affairs Medical Center, Department of Pathology and Laboratory Medicine-113, 2002 Holcombe Blvd, Houston, TX 77030, USA.

Abbreviations: ATR, acid tolerance response; VFA, volatile fatty acid. but are also related to the $\mathrm{pH}$ of the environment and to the dissociation constant of the chemical. Benzoic acid, for instance, is more bactericidal at a given concentration when in an acid environment than it is at a neutral or alkaline $\mathrm{pH}$. Consequently, a greater concentration of benzoic acid is required at $\mathrm{pH} 7$ to kill an organism than is required at $\mathrm{pH}$ 5. This property is due to the fact that the unionized (protonated) form of a weak acid is more permeable to cell membranes than the ionized form (Cherrington et al., 1990, 1991a). Thus, as an environment containing organic acids acidifies, the proportion of undissociated weak acid will increase, making more organic acid available to penetrate a cell. After the unionized form of the acid is inside the cell, the more alkaline intracellular environment $\left(\mathrm{pH}_{\mathrm{i}} 7 \cdot 5-7 \cdot 8\right)$ will cause dissociation of the weak acid and acidification of the cytoplasm. It is generally accepted that the lethal effects of organic acids occur due to the lowering of internal $\mathrm{pH}$ although some argue that the intracellular accumulation of the dissociated weak acid itself plays the most significant role in cell death (Cherrington et al., 1991a; Russell, 1992; Salmond et al., 1984). The reported 
effects of short chain organic acids on Escherichia coli include inhibition of macromolecular synthesis (Cherrington et al., 1990), dissolution of $\Delta \mathrm{pH}$ and selective enzyme sensitivity to lowered $\mathrm{pH}_{\mathrm{i}}$, (reviewed in Cherrington et al., 1991a). The lethal effects apparently do not involve membrane perturbation (Cherrington et al., 1991b). Very little information is available concerning the resistance of enteric organisms to organic acids (Goodson \& Rowbury, 1989; Hentges et al., 1995).

A system that potentially could combat organic acid stress is the acid tolerance response (ATR) of Salmonella typhimurium. The ATR is a complex stress response system that enables $S$. typhimurium to survive brief encounters with extreme acid environments as low as $\mathrm{pH} 3$ (Foster \& Spector, 1995) There are distinct ATR systems induced in exponential-phase and stationary-phase cells (Lee et al., 1994, 1995; Foster \& Hall, 1990). The exponential-phase ATR involves the induction of at least 50 proteins called acid shock proteins (ASPs; Foster, 1991, 1993; Lee et al., 1995). Synthesis of eight of those proteins require an alternative sigma factor called $\sigma^{\mathbf{S}}$ (Lee et al., 1995). The $\sigma^{\mathbf{S}}$ protein, encoded by rpoS, is important as a regulator of stationary phase physiology and during osmotic shock (Loewen \& Hengge-Aronis, 1994). We have recently shown that $\sigma^{\mathrm{s}}$ levels increase upon an acid shock of exponential-phase cells, thereby partially explaining the acid shock induction of this subset of ASPs (Lee et al., 1995; Bearson et al., 1996). These eight $\sigma^{\text {s}}$-dependent proteins are required for sustained induction of acid tolerance. Without them acid tolerance is only transiently induced via acid shock for about $20 \mathrm{~min}$. Stationary-phase cells have, in addition to a general stress resistance induced by stationary phase itself, an acid-pH-inducible system of acid tolerance that is independent of $\sigma^{\mathrm{s}}$ (Lee et al., 1994). Only 15 stationary-phase ASPs are produced, four of which are also induced during the exponential phase.

S. typhimurium often encounters moderately acidic $\mathrm{pH}$ environments ( $\mathrm{pH} 4.5-6)$ that are spiked with organic acids (e.g. intestinal contents and faeces), yet the organism can survive these potentially lethal situations. Because of this we questioned whether or not the ATR might provide a survival advantage even at non-extreme acid $\mathrm{pH}$ values. A previous study examining acid-induced resistance to weak acids in $E$. coli used extremely short exposures at very low $\mathrm{pH}$ ( $\mathrm{pH} 3.5$ ) (Goodson \& Rowbury, 1989). That study used complex medium, which complicates assigning specific systems of tolerance to weak acid protection. E. coli possesses several systems of acid resistance which function in complex medium but which are not active in minimal medium (Lin et al., 1995). S. typhimurium does not appear to possess these complexmedium-dependent acid resistance systems. Consequently, we examined organic acid exposures in $S$. typhimurium at more moderate acid $\mathrm{pH}(\mathrm{pH} \mathrm{4.4)}$ and for periods of time that are more reflective of in vivo situations. In addition, we examined the various ATR systems and several mutants in genes known to affect tolerance to hydrochloric acid for their abilities to survive exposure to weak acids.

\section{METHODS}

Bacterial strains and culture conditions. The bacterial strains used in this study are all derivatives of $S$. typhimurium and are listed in Table 1 . The minimal medium used was medium $\mathrm{E}$ containing $0.4 \%$ glucose (minimal E glucose) (Vogel \& Bonner, 1956). The complex media used were Luria-Bertani (LB) (Davis et al., 1980) and MacConkey (Difco) media. Cultures were grown in semi-aerobic conditions: $3 \mathrm{ml}$ media in $13 \times 100 \mathrm{~mm}$ test tubes, with shaking at 240 r.p.m., at an angle of $45^{\circ}$ and at $37^{\circ} \mathrm{C}$. Antibiotics used included kanamycin $\left(\mathrm{Km}, 100 \mu \mathrm{g} \mathrm{ml}^{-1}\right.$ ) and tetracycline (Tc, 10 or $20 \mu \mathrm{g} \mathrm{ml}^{-1}$ ) for minimal and complex media, respectively.

Exponential-phase ATR. This was measured in the present study essentially as described earlier (Lee et al., 1995) but with modification to test the effects of weak acids. Exponential-phase cells were obtained by making a 1:200 dilution of an overnight culture in fresh minimal $\mathrm{E}$ glucose $(3.0 \mathrm{ml}) \mathrm{pH} 7 \cdot 7$. When the cultures reached a cell density of $2 \times 10^{8}$ c.f.u. $\mathrm{ml}^{-1}$, the weak acid to be tested was added to unadapted cells and the $\mathrm{pH}$ adjusted to a value of 4.4 with $\mathrm{HCl}$ (lethal challenge). Adapted cells were prepared by acid shock treatment at $\mathrm{pH} 4.4$ for $1 \mathrm{~h}$ before adding the weak acid for acid challenge. Viable counts were determined for adapted and unadapted cells at various times after acid challenge. Each experiment was performed a minimum of two and usually three times. The data shown represent mean percentage survival values, with variability for each time point not exceeding $50 \%$ of the stated value (i.e. a $50 \%$ mean survival value ranged between 25 and $75 \%$ upon repetition). Weak acids or their salts were added at the following concentrations unless indicated otherwise: sodium benzoate, $10 \mathrm{mM}$; sodium propionate, $150 \mathrm{mM}$; butyric acid, $50 \mathrm{mM}$; and sodium acetate, $100 \mathrm{mM}$. The VFA cocktail contained $87 \mathrm{mM}$ acetic acid, $25 \mathrm{mM}$ butyric acid and $37 \mathrm{mM}$ sodium propionate and was designed to approximately reflect measured values in intestinal contents (Cummings, 1981). The cocktail was adjusted to $\mathrm{pH} 4.4$ before addition.

Stationary-phase ATR. This was measured as described earlier (Lee et al. 1994). Cells were initially grown to stationary phase in minimal $\mathrm{E}$ glucose $\mathrm{pH} 8$ and harvested. Unadapted cells were directly resuspended at a concentration of $2 \times 10^{8}$ c.f.u. $\mathrm{ml}^{-1}$ in minimal E glucose $\mathrm{pH} 4.4$ containing the weak acid to be tested whereas adapted cells were prepared by resuspension in minimal E glucose $\mathrm{pH} 4.4$ for $2 \mathrm{~h}$ before adding the weak acid.

Table 1. S. typhimurium strains

\begin{tabular}{|c|c|c|}
\hline Strains & Genotype & Source \\
\hline UK1 (x3761) & Wild-type & $\begin{array}{l}\text { R. Curtiss, III } \\
\text { (Curtiss et al., } \\
\text { 1981) }\end{array}$ \\
\hline SF261(TT10287) & $\begin{array}{r}\text { bisD9953:: } \mathrm{MudJ} \\
\text { bis-9941:: } \mathrm{Mud1}\end{array}$ & $\begin{array}{l}\text { J. Roth, University } \\
\text { of Utah, USA. }\end{array}$ \\
\hline JF2690 & UK1 rpoS:: Ap & Lee et al. (1995) \\
\hline JF2733 & UK1 atbR:: Tn10 & $\mathrm{UK} 1 \times \mathrm{P} 22(\mathrm{JF} 2471)$ \\
\hline JF2872 & UK1 $\mathrm{rel} A:: \operatorname{Tn} 10$ & UK1 × P22(SF137) \\
\hline JF2918 & $\begin{array}{l}\mathrm{UK} 1 z d g:: \mathrm{Mu} d \mathrm{~J} \\
\Delta n l p D-r p o S\end{array}$ & $\mathrm{UK} 1 \times \mathrm{P} 22(\mathrm{SF} 261)$ \\
\hline JF2921 & UK1 atr-40::MudJ & $\mathrm{UK} 1 \times \mathrm{P} 22(\mathrm{SF} 261)$ \\
\hline JF2922 & UK1 atr-45::MudJ & $\mathrm{UK} 1 \times \mathrm{P} 22(\mathrm{SF} 261)$ \\
\hline JF2923 & UK1 atr-46::MudJ & $\mathrm{UK} 1 \times \mathrm{P} 22(\mathrm{SF} 261)$ \\
\hline JF2925 & UK1 atr-48::MudJ & $\mathrm{UK} 1 \times \mathrm{P} 22(\mathrm{SF} 261)$ \\
\hline
\end{tabular}


Alternatively, cells grown overnight in minimal E glucose at $\mathrm{pH}$ 8 (unadapted cells) and cells grown overnight in minimal $\mathrm{E}$ glucose at pH 5.5 (adapted) were diluted to $2 \times 10^{6}$ c.f.u. $\mathrm{ml}^{-1}$ in minimal $\mathrm{E}$ glucose $\mathrm{pH} 3 \cdot 0$. Two to three repetitions were performed for each experiment with percentage survival values reproducible to within $50 \%$ of the stated value.

Genetic procedures. Transductions were performed using P22 HT 105/1-int as described previously (Holley \& Foster, 1982; Aliabadi et al., 1988). MudJ transpositions and $\operatorname{Tn} 10$ insertions near $\mathrm{MudJ}$ insertions were constructed as described earlier (Foster \& Bearson, 1994). General mapping of Tn10 insertions were made using the Mud-P22 prophage system described by Benson \& Goldman (1992).

Organic-acid mutant screening procedure. $S$. typhimurium UK1 was infected with P22 phage propagated on SF261, plated on LB for $5 \mathrm{~h}$ and replicated on minimal $\mathrm{E}$ glucose $\mathrm{Km}$. His ${ }^{+}$ $\mathrm{Km}^{R}$ colonies were picked to microtitre dishes containing minimal $\mathrm{E}$ glucose $\mathrm{Km}(100 \mu \mathrm{l})$ for growth and storage (plates were stocked by adding $50 \mu \mathrm{l}$ sterile glycerol per well). Seven thousand colonies were screened as follows for sensitivity to weak acids. Fresh microtitre plates containing $100 \mu \mathrm{l} \mathrm{LB} \mathrm{Km}$ were inoculated, grown overnight and 5-10 $\mu$ l transferred to new microtitre plates containing $100 \mu \mathrm{l} \mathrm{pH} \mathrm{4.4} \mathrm{LB} \mathrm{containing}$ $10 \mathrm{mM}$ benzoate. Plates were incubated at $37^{\circ} \mathrm{C}$ for $1,2,3,4$ and $5 \mathrm{~h}$, and at each time point survivors rescued by transferring 5-10 $\mu$ l culture to MacConkey $\mathrm{Km}$ plates. MacConkey medium was used for rescue because the presence of bile salts and dyes eliminates many acid-damaged cells that are not inviable on LB. Mutants that could not survive a $2 \mathrm{~h}$ exposure to benzoate in this assay were reisolated from the master plate and retested. Eight of the retested mutants maintained the organic-acidsensitive phenotype. Each of these MudJ mutations was transferred to fresh UK1 cells and retested in the microtitre plate assay followed by in vitro ATR assays beforc stocking.

\section{RESULTS AND DISCUSSION}

The exponential-phase and stationary-phase ATR can protect against organic acids

As shown in Fig. 1 (square symbols), organic acids are lethal at moderate concentrations in an acid environment. The $\mathrm{pH} 4.4$ condition itself does not affect viability of $S$. typhimurium over the period of time examined (Foster, 1991). However, the addition of various organic acids (Fig. 1a, b, c) and a VFA cocktail mimicking intestinal and faecal conditions (Fig. 1d) clearly proved lethal over a short period of time at this $\mathrm{pH}$. These organic acid concentrations had no effect on viability if added to $\mathrm{pH} 7-$ grown cells (data not shown). Consequently, we chose to examine what effect inducing the ATR might have in combating the lethal effects of several weak acids. Shown in Fig. 1 are the results of stressing cells at $\mathrm{pH} 4.4$ with $10 \mathrm{mM}$ benzoate (a), $150 \mathrm{mM}$ propionate (b), $100 \mathrm{mM}$ acetate (c) or a VFA cocktail including $87 \mathrm{mM}$ acetic acid, $25 \mathrm{mM}$ butyric acid and $37 \mathrm{mM}$ propionate (d). In each instance, cells that were acid-shock-adapted for $1 \mathrm{~h}$ at $\mathrm{pH}$ $4 \cdot 4$ (Fig. 1, triangles) before adding the weak acid were better prepared to survive the toxic effects of organic weak acids. It appears that the exponential-phase ATR can successfully protect against stress imposed by weak acids.

The stationary-phase ATR provided increased resistance to some, but not all weak acids. The data in Table 2

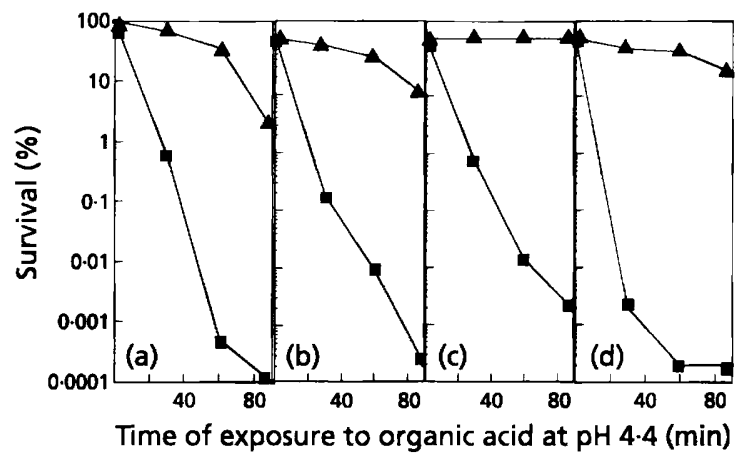

Fig. 1. Effect of the exponential-phase ATR on organic acid resistance. Cells were grown to mid-exponential phase $\left(2 \times 10^{8}\right.$ c.f.u. $\mathrm{ml}^{-1}$ ) in minimal $\mathrm{E}$ glucose $\mathrm{pH} 7.7$ prior to addition of $10 \mathrm{mM}$ benzoate (a), $150 \mathrm{mM}$ propionate (b), $100 \mathrm{mM}$ acetate (c) or a VFA cocktail containing $87 \mathrm{mM}$ acetic acid, $25 \mathrm{mM}$ butyric acid and $37 \mathrm{mM}$ propionate (d). The $\mathrm{pH}$ of unadapted cultures ( $\square$ ) was adjusted to $\mathbf{4 . 4}$ immediately after addition of organic acids. The $\mathrm{pH}$ of adapted cultures $(\boldsymbol{\Lambda})$ was adjusted to 4.4 for $1 \mathrm{~h}$ before adding organic acids. Values represent the means of three experiments and in all cases $100 \%$ survival was equivalent to approximately $2 \times 10^{8}$ c.f.u. $\mathrm{ml}^{-1}$.

illustrates that inducing the stationary-phase ATR by overnight growth at $\mathrm{pH} 5.5$ provided protection against propionate and acetate but not against benzoate, even though the benzoate concentration was much lower than the other two weak acids tested. This finding supports the notion that the lethal effects of some weak acids go beyond simply acidifying internal $\mathrm{pH}$ (Cherrington et al., 1991a; Russell, 1992; Salmond et al. 1984). The nature of the anion appears to have a significant effect, at least in stationary-phase cells. The fact that exponential-phase cells in which acid tolerance had been induced were better able to tolerate weak acids than stationary-phase cells implies different mechanisms of tolerance occur in exponential-phase versus stationary-phase cells.

It is important to note that simple growth arrest did not induce tolerance to acid stress. Previous studies have attempted to induce acid tolerance by osmotic shock, $\mathrm{H}_{2} \mathrm{O}_{2}$ and temperature shock. None of these conditions successfully induced cross protection against acid conditions (Foster \& Hall, 1990). In addition, it is clear that protein synthesis is required for the development of acid tolerance (Foster \& Hall, 1990; Foster, 1991, 1993; Lee et al., 1995; Bearson et al., 1996).

\section{Growth in organic acids does not induce organic acid resistance at low pH}

As discussed above, acid shock involving growth arrest successfully induced resistance to weak acids. An investigation was conducted to determine if resistance to weak acids could be induced by the weak acids themselves without growth arrest, i.e. will growth in a sublethal concentration of organic acid induce an adaptive response or does acid shock alone induce resistance to organic acids? Cells were grown in minimal E glucose containing either $6 \mathrm{mM}$ acetate, $0.25 \mathrm{mM}$ benzoate or $0.75 \mathrm{mM}$ 
Table 2. The effect of stationary-phase ATR on resistance to organic acids

S. typhimurium UK1 was grown overnight in minimal E glucose $\mathrm{pH} 8$ (unadapted) or minimal $\mathrm{E}$ glucose pH 5.5 (adapted). Cultures were diluted in minimal E glucose $\mathrm{pH} 4.4$ containing $150 \mathrm{mM}$ acetate, $10 \mathrm{mM}$ benzoate or $100 \mathrm{mM}$ propionate. Results are the means of three experiments.

\begin{tabular}{|c|c|c|c|c|c|c|}
\hline \multirow{3}{*}{$\begin{array}{l}\text { Exposure } \\
\text { (h) }\end{array}$} & \multicolumn{6}{|c|}{ Survival (\%) } \\
\hline & \multicolumn{2}{|c|}{ Acetate } & \multicolumn{2}{|c|}{ Benzoate } & \multicolumn{2}{|c|}{ Propionate } \\
\hline & Unadapted & Adapted & Unadapted & Adapted & Unadapted & Adapted \\
\hline 1 & $<0.04$ & 24 & $<0.04$ & $<0.04$ & 0.76 & $44 \cdot 4$ \\
\hline 2 & $<0.04$ & $0 \cdot 11$ & $<0.04$ & $<0.04$ & $<0.03$ & $15 \cdot 5$ \\
\hline 3 & $<0.04$ & $<0.04$ & $<0.04$ & $<0.04$ & $<0.03$ & $5 \cdot 4$ \\
\hline 4 & $<0.04$ & $<0.04$ & $<0.04$ & $<0.04$ & $<0.03$ & $1 \cdot 3$ \\
\hline
\end{tabular}

propionate and allowed to mid-exponential phase. The concentrations of organic acids were 5- to 10-fold below the minimum inhibitory concentrations at $\mathrm{pH} 7$. Each culture plus a control culture grown in the absence of added organic acid was diluted $1 / 1000$ in a series of media at $\mathrm{pH} 4.4$ containing $150 \mathrm{mM}$ acetate, $5 \mathrm{mM}$ benzoate or $100 \mathrm{mM}$ propionate. Viability was measured over the course of several hours. None of these growth conditions resulted in enhanced resistance to the organic acids at low $\mathrm{pH}$ (data not shown); acid shock adaptation was required to develop this type of resistance.

\section{Effect of rpoS, fur, atp and atbR mutations on organic acid ATR}

Several mutations that affect acid tolerance at $\mathrm{pH} 3$ were previously characterized. The genes involved include the alternative sigma factor locus $r$ poS (Lee et al., 1995), the ferric uptake regulator, fur (Foster \& Hall, 1992; Foster, 1991), the major proton translocating ATPase atp (Foster \& Hall, 1991) and an apparent regulator of acid tolerance, atbR (Foster \& Bearson, 1994; B. Bearson \& J. W. Foster, unpublished). These mutations were tested for their effects on resistance to weak acids. Fig. 2(b) shows that mutations in rpoS have a severe dampening effect on inducible resistance to organic acid similar to the reported effect of rpoS on extreme ( $\mathrm{pH} 3$ ) acid tolerance. The $a t b \mathrm{R}$ mutation, however, had an effect opposite to that reported earlier for extreme acid tolerance. This mutation was shown to increase tolerance to $\mathrm{pH} 3$ but, surprisingly, increased sensitivity to organic acids even in acid-shockadapted cells (Fig. 2c). Mutations in fur and atp did not have any obvious effect on inducible organic acid resistance (data not shown). This was not unexpected since their effects are seen mostly on the transient ATR observed in rpoS mutants (Lee et al., 1995). A relA mutation not known to affect the ATR likewise had no effect upon inducible resistance to organic acids (Fig. 2d).

\section{Isolation of organic-acid-sensitive mutants}

The protonophore dinitrophenol was previously used to isolate mutants defective in the transient ATR (Foster \&

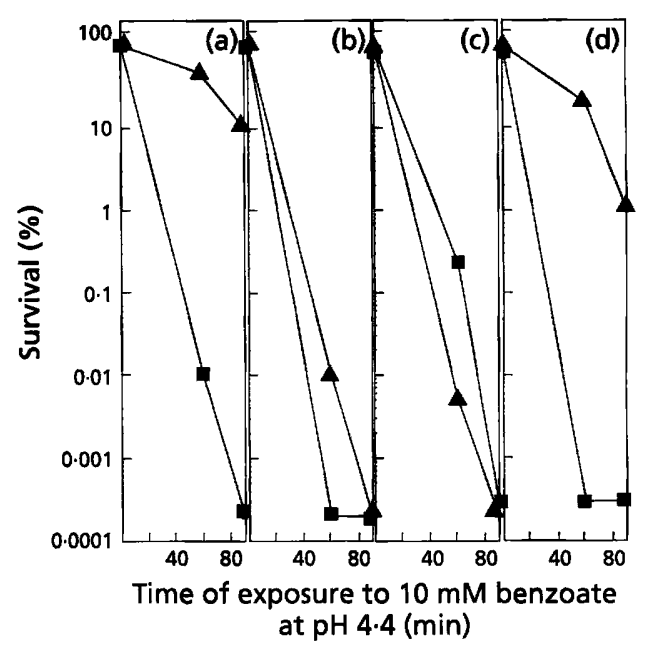

Fig. 2. Effects of rpoS, atbR and relA mutations on resistance to benzoate. S. typhimurium UK1 (a), and rpoS (b), atbR (c) and relA (d) mutants were grown and treated with $10 \mathrm{mM}$ benzoate at $\mathrm{pH} 4.4$ as described in the legend to Fig. 1. $\square$, Unadapted cultures; $\Delta, \mathrm{pH}$ 4-4-adapted cultures. Values represent the means of three experiments and in all cases $100 \%$ survival was equivalent to approximately $2 \times 10^{8}$ c.f.u. $\mathrm{ml}^{-1}$.

Bearson, 1994) but there has been little success using this technique to isolate mutations that affect the sustained ATR. The observation that the ATR can provide tolerance to organic acids provided a new mutant screening methodology. Microtitre plates containing LB $\mathrm{Km}$ were used to prepare a series of random $\mathrm{MudJ}$ insertion mutants for testing. Overnight cultures were replicated to a second series of microtitre plates containing LB plus $10 \mathrm{mM}$ benzoate. This is a lethal screening condition. After $2 \mathrm{~h}$, survivors were identified following replication to MacConkey lactose medium. Insertion mutants that could not survive the $2 \mathrm{~h}$ in benzoic acid were picked from the master microtitre dish and their insertions transferred to fresh UK1 cells. The tolerance of these mutants to a weak acid stress (benzoate) at $\mathrm{pH} 4 \cdot 4$ and to an extreme acid stress $(\mathrm{pH} 3)$ are shown in Figs 3 


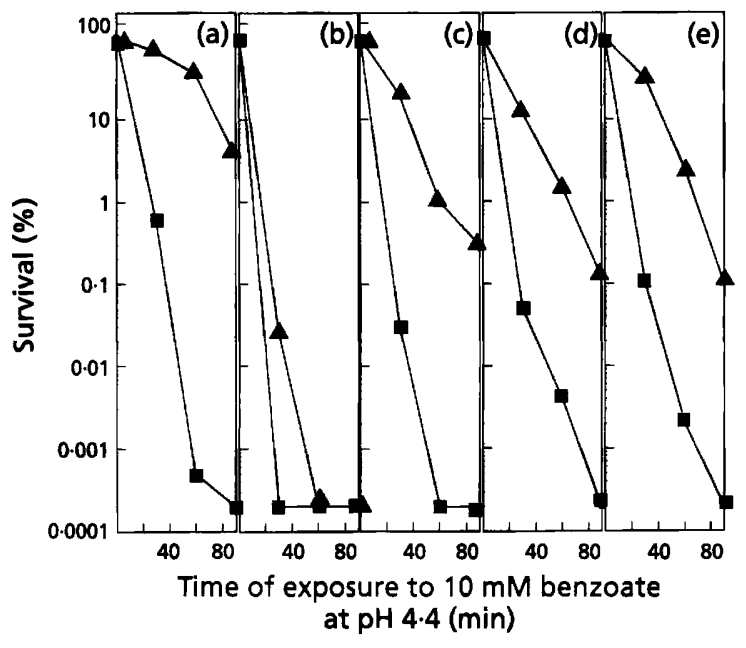

Fig. 3. Organic acid ATR of mutants sensitive to organic acids. S. typhimurium strains UK1 (a), JF2918 (b), JF2921 (c), JF2923 (d) and JF2925 (e) were grown and treated with $10 \mathrm{mM}$ benzoate at $\mathrm{pH} 4.4$ as described in the legend to Fig. 1. $\square$, Unadapted cultures: $\Delta, \mathrm{pH}^{4} 4$-adapted cultures. Values represent the means of three experiments and in all cases $100 \%$ survival was equivalent to approximately $2 \times 10^{8}$ c.f.u. $\mathrm{ml}^{-1}$.

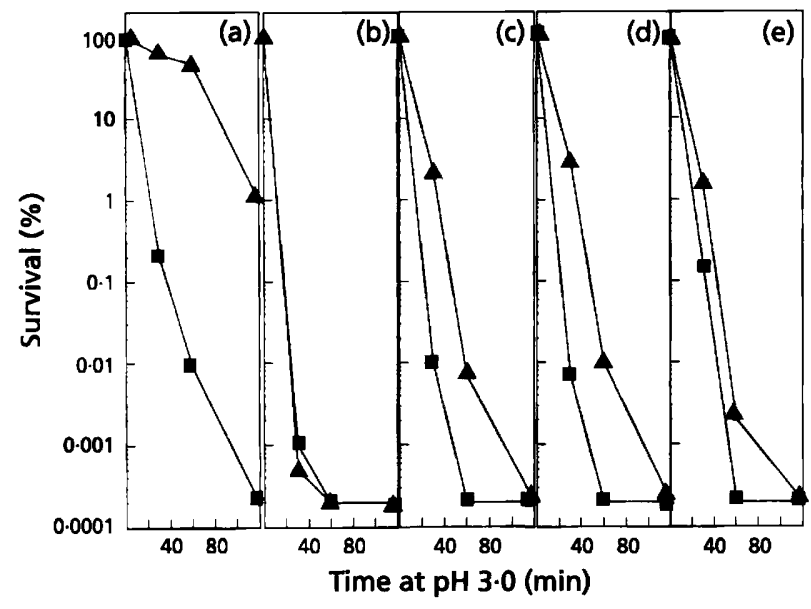

Fig. 4. Strong acid $(\mathrm{HCl})$ ATR of mutants sensitive to organic acids. S. typhimurium strains UK1 (a), JF2918 (b), JF2921 (c), JF2923 (d) and JF2925 (e) were treated as described in the legend to Fig. 1 without any addition of organic acids and the $\mathrm{pH}$ adjusted to $\mathrm{pH} 3$. $\square$, Unadapted cultures; $\Delta, \mathrm{pH} \mathrm{4.4-}$ adapted cultures. Values represent the means of three experiments and in all cases $100 \%$ survival was equivalent to approximately $2 \times 10^{8}$ c.f.u. $\mathrm{ml}^{-1}$.

and 4, respectively. The insertion in JF2918 dramatically diminished tolerance to both conditions. The other three insertions eliminated extreme acid tolerance but, surprisingly, had little effect on organic acid tolerance even though the cells were initially isolated as being organic-acid-sensitive. Part of the reason for this apparent paradox appears to be the use of MacConkey medium in the initial mutant selection strategy. The bile salts and dyes in this medium are known to inhibit recovery of aciddamaged cells (Roth \& Keenan, 1971; Przybylski \& Witter, 1979). Since the organic acid tolerance assay involves recovery on $\mathrm{LB}$, the effect of these mutations on organic acid damage were minimized. In addition, the results suggest that the acid stress inflicted by $\mathrm{pH} 3$ is more severe than that by $\mathrm{pH} 4 \cdot 4$ plus organic acids since these three mutants survived the latter but not the former condition.

\section{The acid-sensitive insertion mutations map to the rpos region}

Cotransductional analysis with a library of $\operatorname{Tn} 10$ insertions placed the MudJ insertions in strains JF2921, JF2923 and JF2925 near rpoS. However, only a $50 \%$ reduction in catalase activity was observed (data not shown) indicating these mutations are not in rpoS but probably interrupt transcription of rpoS from one or more of the multiple promoters for this gene (Takayanagi et al. 1994; Lange et al. 1995). Cloning and sequence analysis of the MudJ fusion junction in JF2918 revealed that the insertion in this strain occurred just upstream of the $n l p D$ gene, which itself is upstream of $r p o S$. The strain does not produce $\sigma^{\mathrm{S}}$ as determined by Western blotting (data not shown) and could not be transduced with $\operatorname{Tn} 10$ insertions in or near $r p o S$, although transductions with other $\operatorname{Tn} 10$ insertions were normal. The results suggest that a deletion extending through rpoS occurred adjacent to the $\mathrm{MudJ}$ insertion making JF2918 refractory to recombination in this area of the chromosome. The complete loss of $\sigma^{\mathrm{s}}$ made this strain sensitive to both organic and $\mathrm{HCl}$ acid stress. The residual $\sigma^{\mathbf{S}}$ present in the other strains permitted a degree of organic acid resistance in liquid culture but did not confer tolerance to strong acid ( $\mathrm{pH} 3$ ). This again suggests that $\mathrm{pH} 3$ acid stress is more severe than the stress imposed by weak acids at $\mathrm{pH} \mathrm{4.4}$. The fact that rpoS mutants are sensitive to organic acid stress confirms that growth arrest alone will not confer resistance to organic acids.

The results from this work have revealed that the inducible ATR, in addition to its importance for surviving strong acid environments ( $\mathrm{pH} \mathrm{3)}$, is an important means of surviving exposures to weak acids prevalent in the gastro-intestinal environment. Thus, the ATR will protect $S$. typhimurium against both types of acid stress that the organism will encounter during pathogenesis. The alternative sigma factor $\sigma^{\mathbf{s}}$ clearly plays an important role in protecting against the lethal effects of weak acids. Preliminary evidence suggests that the primary role of $\sigma^{\mathrm{S}}$ in acid tolerance may be to handle the stress imposed by weak acids. It may not be required for acid tolerance in the absence of weak acids (B. Bearson \& J. W. Foster, unpublished data).

\section{ACKNOWLEDGEMENTS}

This work was supported by a grant from the NIH to J.W.F (GM48017) and from the Korean Ministry of Education to H.S.B. The authors thank R. Burgess for providing anti- $\sigma^{\mathbf{s}}$ antibody. 


\section{REFERENCES}

Aliabadi, Z., Park, Y. K., Slonczewski, S. L. \& Foster, J. W. (1988). Novel regulatory loci controlling oxygen and $\mathrm{pH}$-regulated gene expression in Salmonella typhimurium. J Bacteriol 170, 842-851.

Bearson, S. M. D., Benjamin, W. H. J., Swords, W. E. \& Foster, J. W. (1996). Acid shock induction of RpoS is mediated by the mouse virulence gene mviA of Salmonella typhimurium. $J$ Bacteriol 178, 2572-2579.

Benson, N. R. \& Goldman, B. S. (1992). Rapid mapping in Salmonella typhimurium with Mud-P22 prophages. J Bacteriol 174, 1673-1681.

Bergeim, O. (1940). Toxicity of intestinal volatile fatty acids for yeast and E. coli. J Infect Dis 66, 222-234.

Cherrington, C. A., Hinton, M. \& Chopra, I. (1990). Effect of shortchain organic acids on macromolecular synthesis in Eschericbia coli. $J$ Bacteriol 68, 69-74.

Cherrington, C. A., Hinton, M., Mead, G. C. \& Chopra, I. (1991a). Organic acids: chemistry, antibacterial activity and practical applications. Adv Microb Physiol 32, 87-108.

Cherrington, C. A., Hinton, M., Pearson, G. R. \& Chopra, I. (1991b). Short-chain organic acids at $\mathrm{pH} 5 \cdot 0 \mathrm{kill}$ Eschericbia coli and Salmonella spp. without causing membrane perturbation. J Appl Bacteriol 70, 161-165.

Cummings, J. H. (1981). Short chain fatty acids in the human colon. Gut 22, 763-779.

Cummings, J. H., Pomare, E. W., Branch, W. J., Naylor, C. P. E. \& MacFarlane, G. T. (1987). Short chain fatty acids in human large intestine, portal, hepatic and venous blood. Gut 28, 1221-1227.

Curtiss, R., III, Porter, S. B., Munson, M., Tinge, S. A., Hassan, J. O., Gentry-Weeks, C. \& Kelly, S. M. (1981). Nonrecombinant and recombinant avirulent Salmonella vaccines for poultry. In Colonization Control of Human Bacterial Enteropathogens in Poultry, pp. 169-198. New York: Academic Press.

Davis, R. W., Botstein, D. \& Roth, J. R. (1980). A Manual for Genetic Engineering. Advanced Bacterial Genetics. Cold Spring Harbor, NY: Cold Spring Harbor Laboratory.

Eklund, T. (1980). Inhibition of growth and uptake processes in bacteria by some chemical food preservatives. J Appl Bacteriol 48, 423-432.

Fay, J. P. \& Farias, R. N. (1975). The inhibitory action of fatty acids on the growth of Eschericbia coli. J Gen Microbiol 91, 233-240.

Foster, J. W. (1991). Salmonella acid shock proteins are required for the adaptive acid toletance response. J Bacteriol 173, 6896-6902.

Foster, J.W. (1993). The acid tolerance response of Salmonella typbimurium involves transient synthesis of key acid shock proteins. $J$ Bacteriol 175, 1981-1987.

Foster, J. W. \& Bearson, B. (1994). Acid sensitive mutants of Salmonella typhimurium identified through a dinitrophenol selection strategy. J Bacteriol 176, 2596-2602.

Foster, J. W. \& Hall, H. K. (1990). Adaptive acidification tolerance response of Salmonella typhimurium. J Bacteriol 172, 771-778.

Foster, J. W. \& Hall, H. K. (1991). Inducible $\mathrm{pH}$ homeostasis and the acid tolerance response of Salmonella typhimurium. J Bacteriol 173, 5129-5135.

Foster, J.W. \& Hall, H. K. (1992). The effect of Salmonella typhimurium ferric-uptake regulator (fur) mutations on iron and $\mathrm{pH}$ regulated protein synthesis. J Bacteriol 174, 4317-4323.

Foster, J. W. \& Spector, M. (1995). How Salmonella survives against the odds. Annu Rev Microbiol 49, 145-174.

Freese, E., Sheu, C. W. \& Galliers, E. (1973). Functions of lipophilic acids as antimicrobial food additives. Nature 241, 321-325.

Goodson, M. \& Rowbury, R. J. (1989). Resistance of acidhabituated Escherichia coli to organic acids and its medical and applied significance. Lett Appl Microbiol 8, 211-214.

Hentges, D. J., Marsch, W. W., Petschow, B. W., Rahman, M. E. \& Dougherty, S. H. (1995). Influence of a human milk diet on colonisation resistance mechanisms against Salmonella typhimurium in human faecal bacteria-associated mice. Microb Ecol Health Dis 8, 139-149.

Holley, E. A. \& Foster, J. W. (1982). Bacteriophage P22 as a vector for $\mathrm{Mu}$ mutagenesis in Salmonella typhimurium: isolation of nad-lac and pnc-lac gene fusions. J Bacteriol 152, 959-962.

Lange, R., Fischer, D. \& Hengge-Aronis, R. (1995). Identification of transcriptional start sites and the role of ppGpp in the expression of $r p o S$, the structural gene for the $\sigma^{\mathrm{s}}$ subunit of RNA polymerase in Escherichia coli. J Bacteriol 177, 4676-4680.

Lee, I. S., Slonczewski, J. L. \& Foster, J. W. (1994). A low-pH inducible stationary phase acid tolerance response in Salmonella typbimurium. J Bacteriol 176, 1422-1426.

Lee, I. S., Lin, J., Hall, H. K., Bearson, B. \& Foster, J. W. (1995). The stationary-phase sigma factor $\sigma^{\mathbf{s}}$ (RpoS) is required for a sustained acid tolerance response in virulent Salmonella typbimurium. Mol Microbiol 17, 155-167.

Lin, J., Lee, I. S., Frey, J., Slonczewski, J. L. \& Foster, J. W. (1995). Comparative analysis of extreme acid survival in Salmonella typhimurium, Shigella flexneri and Escherichia coli. J Bacteriol 177, 4097-4104.

Loewen, P. C. \& Hengge-Aronis, R. (1994). The role of the sigma factor $\sigma^{\mathbf{s}}(\mathrm{KatF})$ in bacterial global regulation. Annu Rev Microbiol $48,53-80$.

MacFarlane, G. T., Gibson, G. R. \& Cummings, J. H. (1992). Comparison of fermentation reactions in different regions of the human colon. J Appl Bacteriol 72, 57-64.

Przybylski, K. \& Witter, L. (1979). Injury and recovery of Escberichia coli after sublethal acidification. Appl Environ Microbiol 37, 261-265.

Roth, L. \& Keenan, D. (1971). Acid injury of Escherichia coli. Can J Microbiol 17, 1005-1008.

Russell, J. B. (1992). Another explanation for the toxicity of fermentation acids at low $\mathrm{pH}$ : anion accumulation versus uncoupling. $J$ Appl Bacteriol 73, 363-370.

Salmond, C. V., Kroll, R. G. \& Booth, I. R. (1984). The effect of food preservatives on $\mathrm{pH}$ homeostasis in Escherichia coli. J Gen Microbiol 130, 2845-2850.

Takayanagi, Y., Tanaka, K. \& Takahashi, H. (1994). Structure of the $5^{\prime}$ upstream region and regulation of the $r p o S$ gene of Escherichia coli. Mol Gen Genet 243, 525-531.

Vogel, H. J. \& Bonner, D. M. (1956). Acetylornithase of Eschericbia coli: partial purification and some properties. $J$ Biol Chem 218 , 97-106.

Received 9 May 1996; revised 25 July 1996; accepted 26 July 1996. 